\title{
Regresi Nonparametrik Spline Truncated untuk Memodelkan Persentase Unmet Need di Kabupaten Gresik
}

\author{
Camelia Nanda Sholicha, I Nyoman Budiantara, dan Madu Ratna \\ Departemen Statistika, Fakultas Matematika, Komputasi dan Sains Data \\ Institut Teknologi Sepuluh Nopember (ITS) \\ e-mail:i_nyoman_b@statistika.its.ac.id
}

\begin{abstract}
Abstrak-Kabupaten Gresik merupakan wilayah yang mengalami penurunan persentase unmet need sehingga pada tahun 2017 menjadi urutan terendah kedua di Provinsi Jawa Timur yaitu sebesar 15,6\%. Faktor-faktor yang mempengaruhi seperti petugas penyuluh informasi, tempat pelayanan $\mathrm{KB}$, persentase keluarga miskin dan persentase pendidikan terakhir lebih dari SMA yang ditamatakan kepala keluarga diduga cukup berpengaruh dalam capaian Kabupaten Gresik dalam menangani kejadian unmet need. Metode yang sesuai digunakan dalam penelitian yaitu analisis regresi nonparametrik Spline Truncated karena data tidak membentuk sebuah pola tertentu serta menggunakan titik knot optimum berdasarkan nilai Generalized Cross Validation (GCV) yang minimum. Dalam penelitian ini, karakteristik kecamatan dengan persentase unmet need di Kabupaten Gresik sangat tinggi dan tidak memenuhi SPM. Model regresi nonparametrik spline truncated terbaik dengan menggunakan kombinasi titik knot yaitu satu titik knot pada variabel cakupan PKB/PLKB $\left(x_{1}\right)$, satu titik knot pada variabel cakupan tempat pelayanan KB $\left(x_{2}\right)$, dua titik knot pada variabel persentase keluarga miskin $\left(x_{3}\right)$, serta dua titik knot pada variabel persentase pendidikan terakhir lebih dari SMA yang ditamatkan oleh KK $\left(x_{4}\right)$. Nilai koefisien determinasi yang dihasilkan dari model ini adalah sebesar $88,09 \%$.
\end{abstract}

Kata Kunci-GCV, Unmet Need, Regresi Nonparametrik, Spline Truncated, Titik Knot.

\section{PENDAHULUAN}

$\mathrm{I}$ NDONESIA merupakan negara dengan jumlah penduduk terbanyak di dunia, dimana Indonesia berada di posisi ke4 dengan jumlah penduduk sebesar 253,60 juta jiwa yang bersaing dengan Brasil di posisi ke-5 [1]. Salah satu upaya untuk menekan ledakan penduduk yaitu dengan pencangan program KB. Provinsi Jawa Timur tergolong dalam penyumbang penduduk terbanyak di Indonesia, sehingga Perwakilan BKKBN Jawa Timur masih akan menghadapi tantangan di masa mendatang dimana BKKBN akan terus memberikan pelayanan KB kepada pasangan usia subur dan mengingatkan pentingnya program KB. Kabupaten Gresik adalah salah satu wilayah di Provinsi Jawa Timur yang sukses dalam bidang mengatasi fertilitas dengan penggunaan KB pada tahun 2015. Namun pada tahun 2017 hal tersebut berbanding terbalik dimana data KBPP\&PA Kabupaten Gresik menunjukkan bahwa keikutsertaan KB dari tahun 2014 hingga 2017 tergolong stagnan sedangkan jumlah PUS semakin meningkat. Salah satu cara untuk meningkatkan dan mempertahankan prestasi yang telah berhasil dilakukan oleh Kabupaten Gresik dalam keikutsertaan KB ini dengan merujuk ke sasaran KB yaitu menurunnya kebutuhan ber-KB yang tidak terpenuhi (unmet need) [2]. Hal tersebut membuat menurun akibat adanya PUS yang tergolong keluarga bukan peserta KB tersebut hingga mencapai 15,6\% pada tahun 2017. Persentase unmet need di Kabupaten Gresik meningkat lebih dari 2 kali lipat target yang dicanangkan pemerintah yaitu sebesar 7,03 persen setelah 3 tahun berturut-turut berhasil menurunkan persentase unmet need tersebut. Selain itu juga persentase unmet need Kabupaten Gresik tersebut membuat rentang yang sangat jauh dibawah persentase unmet need Provinsi Jawa Timur yang mencapai 10,45 persen di tahun 2017. Hal tersebut berawal dari 16 kecamatan dari 18 kecamatan di Kabupaten Gresik yang memiliki persentase unmet need cukup tinggi atau diatas 7,03\% hingga terdapat persentase yang lebih dari 4 kali dari target pemerintah yaitu Kecamatan Bungah. Selanjutnya, pemerintah Kabupaten Gresik diharapkan dapat meningkatkan pencapaian Kabupaten Gresik dalam program $\mathrm{KB}$ dan fertilitas dengan pengoptimalan ketersediaan sumber daya pelayanan KB. Oleh karena itu penelitian ini dilakukan untuk mengetahui besarnya faktor yang mempengaruhi tingginya persentase unmet need tiap wilayah kecamatan di Kabupaten Gresik. Faktor yang mempengaruhi kondisi unmet need di wilayah tersebut yaitu ketersediaan sumber daya pelayanan $\mathrm{KB}$ seperti jumlah petugas penyuluh informasi mengenai KB di kecamatan. Faktor yang selanjutnya yaitu fasilitas kesehatan yang tersedia di tiap kecamatan, karena kemudahan dalam menjangkau fasilitas kesehatan yang ada di kecamatan tersebut membuat masyarakat lebih terasa efisien untuk mengikuti program KB. Selain kedua faktor tersebut terdapat faktor tingkat kemiskinan keluarga dimana apabila sebuah keluarga semakin memiliki tingkat kemiskinan dibawah rata-rata maka akan mengakibatkan naiknya kondisi unmet need tersebut. Faktor yang terakhir yaitu pendidikan terakhir lebih dari SMA yang ditamatkan kepala keluarga, dimana ketika kepala keluarga memiliki latar belakang pendidikan yang tergolong tinggi, maka kepala keluarga/suami tersebut dapat membantu istri dalam penentuan penggunaan kontrasepsi. Sehingga metode yang sesuai digunakan dalam penelitian yaitu analisis regresi nonparametrik Spline Truncated, karena kondisi faktor-faktor yang mempengaruhi tidak membentuk suatu pola tertentu. Serta akan diketahui karakteristik dari persentase unmet need yang dipengaruhi 
oleh faktor-faktor tersebut. Dalam penelitian ini menggunakan metode regresi spline linier 1 orde dengan 1 titik knot, 2 titik knot dan kombinasi titik knot. Sedangkan untuk pemilihan titik knot yang optimal menggunakan metode GCV atau Generalized Cross Validation.

\section{TINJAUAN PUSTAKA}

\section{A. Statistika Deskriptif}

Statistika Deskriptif merupakan bagian statistik yang membahas tentang metode-metode untuk menyajikan data sehingga menarik dan informatif. Dalam statistika deskriptif, terdapat 2 jenis ukuran data yaitu ukuran pemusatan dan penyebaran data [3].

\section{B. Analisis Regresi Nonparametrik Spline Truncated}

Regresi nonparametrik digunakan apabila bentuk kurva regresi tidak diketahui atau informasi tentang bentuk pola data dimasa lalu tidak lengkap. Salah satu metode estimasi regresi nonparametrik adalah Spline [4]. Metode Spline ini sangat baik dalam memodelkan data yang polanya berubahubah pada sub interval tertentu [5] Fungsi spline $f(x)$ berorde $q$ dengan titik knot $K_{l}, K_{2}, \ldots, K_{r}$ dapat dituliskan sebagai berikut.

$$
f(x)=\sum_{u=0}^{q} \beta_{u} x^{u}+\sum_{k=1}^{r} \beta_{q+k}\left(x-K_{k}\right)_{+}^{q}
$$

dengan fungsi truncated

$$
\left(x-K_{k}\right)_{+}^{q}= \begin{cases}\left(x-K_{k}\right)^{q} & , x \geq K_{k} \\ 0 & , x<K_{k}\end{cases}
$$

Dalam pembahasan ini, diberikan data berpasangan $\left(x_{1 i}, x_{2 i}, \cdots, x_{p i}, y_{i}\right)$ dimana $i=1,2, \ldots, n$ dan $j=1,2, \ldots, p$. Selanjutnya $f_{j}\left(x_{j i}\right)$ termuat pada ruang Spline derajat 1 dengan $r$ titik knot yang dituliskan seperti persamaan berikut [6].

$$
f_{j}\left(x_{j i}\right)=\sum_{u=0}^{1} \beta_{j u} x_{j i}^{u}+\sum_{k=1}^{r} \beta_{j(1+k)}\left(x_{j i}-K_{j k}\right)_{+}^{1}
$$

Berdasarkan $f_{j}\left(x_{j i}\right)$ tersebut, model regresi nonparametrik Spline Truncated multivariabel dapat dituliskan seperti per-samaan berikut [7].

$$
y_{i}=\beta_{0}^{*}+\sum_{j=1}^{p} \beta_{j 1} x_{j i}+\sum_{j=1}^{p} \sum_{k=1}^{r} \beta_{j(1+k)}\left(x_{j i}-K_{j k}\right)_{+}+\varepsilon_{i}
$$

Dimana $\beta_{0}^{*}=\sum_{j=1}^{p} \beta_{j 0}$ dengan fungsi Truncated seperti pada persamaan berikut [8].

$$
\left(x_{j i}-K_{j k}\right)_{+}= \begin{cases}\left(x_{j i}-K_{j k}\right) & , x_{j i} \geq K_{j k} \\ 0 & , x_{j i}<K_{j k}\end{cases}
$$

Model regresi Spline Truncated multivariabel tersebut dapat disajikan dalam bentuk $\mathbf{y}=\mathbf{X} \boldsymbol{\beta}+\boldsymbol{\varepsilon}$ dimana uraian matriksnya ditunjukkan oleh persamaan berikut [9].

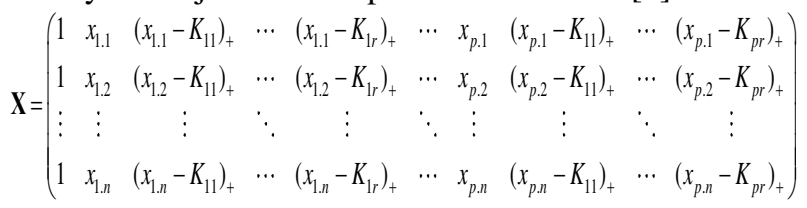

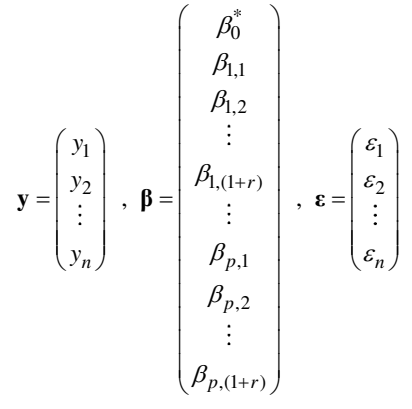

\section{Pemilihan Titik Knot Optimal}

Salah satu metode untuk mencari titik knot optimal yang sering dipakai adalah GCV [10]. Jika dibandingkan dengan metode lain misalnya Cross Validation (CV), metode GCV memiliki sifat optimal asimtotik [11].

$\operatorname{GCV}\left(\mathrm{K}_{1}, \mathrm{~K}_{2}, \ldots, \mathrm{K}_{r}\right)=\frac{\operatorname{MSE}\left(\mathrm{K}_{1}, \mathrm{~K}_{2}, \ldots, \mathrm{K}_{r}\right)}{\left(n^{-1} \operatorname{trace}\left[\mathbf{I}-A\left(\mathrm{~K}_{1}, \mathrm{~K}_{2}, \ldots, \mathrm{K}_{r}\right)\right]\right)^{2}}$

dengan $\mathbf{I}$ adalah matriks identitas, $\mathrm{n}$ adalah jumlah pengamatan, $\mathbf{A}\left(\mathrm{K}_{1}, \mathrm{~K}_{2}, \ldots, \mathrm{K}_{r}\right)$ adalah matriks $\mathbf{X}\left(\mathbf{X}^{\mathbf{T}} \mathbf{X}\right)^{-1} \mathbf{X}^{\mathbf{T}}$ dan $\operatorname{MSE}\left(\mathrm{K}_{1}, \mathrm{~K}_{2}, \ldots, \mathrm{K}_{r}\right)$ sebagai berikut [5].

$$
\operatorname{MSE}\left(\mathrm{K}_{1}, \mathrm{~K}_{2}, \ldots, \mathrm{K}_{r}\right)=n^{-1} \sum_{i=1}^{n}\left(y_{i}-\hat{y}_{i}\right)^{2}
$$

\section{Estimasi Parameter Model Regresi Nonparametrik}

Spline Truncated

Untuk mendapatkan estimasi model regresi nonparametrik Spline Truncated multivariabel dapat menggunakan metode OLS (Ordinary Least square) sehingga diperoleh jumlah kuadrat error pada persamaan berikut.

$$
\begin{aligned}
Q(\beta) & =\sum_{i=1}^{n} \varepsilon_{i}^{2} \\
& =\sum_{i=1}^{n}\left(y_{i}-\left(\beta_{0}^{*}+\sum_{j=1}^{p} \beta_{j 1} x_{j i}+\sum_{j=1}^{p} \sum_{k=1}^{r} \beta_{j(1+k)}\left(x_{j i}-K_{j k}\right)_{+}\right)\right)^{2}
\end{aligned}
$$

Bentuk $Q(\boldsymbol{\beta})$ tersebut juga dapat dituliskan dalam bentuk persamaan $Q(\boldsymbol{\beta})=\mathbf{y}^{\prime} \mathbf{y}-2 \boldsymbol{\beta}^{\prime} \mathbf{X}^{\prime} \mathbf{y}+\boldsymbol{\beta}^{\prime} \mathbf{X}^{\prime} \mathbf{X} \boldsymbol{\beta}$. Setelah didapatakan persamaan tersebut maka diderivatifkan parsial dan di sama dengankan nol, lalu dikalikan dengan $\left(\mathbf{X}^{\prime} \mathbf{X}\right)^{-1}$ untuk kedua ruas sehingga akan diperoleh persamaan $\widehat{\boldsymbol{\beta}}=\left(\mathbf{X}^{\prime} \mathbf{X}\right)^{-1} \mathbf{X}^{\prime} \mathbf{y}[12]$.

\section{E. Pengujian Signifikansi Parameter Model}

Pengujian parameter model regresi dilakukan untuk mengetahui signifikansi hubungan antara variabel respon dengan variabel prediktor.

\section{Uji Serentak}

Hipotesis yang digunakan untuk parameter-parameter model regresi nonparametrik Spline Truncated orde q dan titik-titik knot $\mathrm{K}_{1}, \mathrm{~K}_{2}, \ldots, \mathrm{K}_{\mathrm{r}}$ sebagai berikut.

$H_{0}: \beta_{11}=\beta_{12}=\ldots=\beta_{p(1+r)}=0$

$H_{1}$ : minimal ada satu $\beta_{j l} \neq 0, j=1,2, . ., p ; l=1,2, . ., 1+r$

Tabel 1.

ANOVA Untuk Regresi Nonparametrik Spline Truncated

\begin{tabular}{ccccc}
\hline \hline $\begin{array}{c}\text { Sumber } \\
\text { Variasi }\end{array}$ & $\begin{array}{c}\text { Derajat } \\
\text { Bebas }\end{array}$ & Jumlah Kuadrat & $\begin{array}{c}\text { Rataan } \\
\text { Kuadrat }\end{array}$ & $\mathrm{F}_{\text {hitung }}$ \\
\hline \multirow{2}{*}{ Regresi } & $\mathrm{p}(1+\mathrm{r})$ & $\sum_{i=1}^{n}\left(\hat{y}_{i}-\bar{y}\right)^{2}$ & $\frac{\sum_{i=1}^{n}\left(\hat{y}_{i}-\bar{y}\right)^{2}}{p(1+r)}$ & $\frac{M S R}{M S E}$ \\
\hline
\end{tabular}




\begin{tabular}{ccccc}
\hline \hline $\begin{array}{c}\text { Sumber } \\
\text { Variasi }\end{array}$ & $\begin{array}{c}\text { Derajat } \\
\text { Bebas }\end{array}$ & Jumlah Kuadrat & $\begin{array}{c}\text { Rataan } \\
\text { Kuadrat }\end{array}$ & F hitung $^{n}$ \\
\cline { 1 - 3 } Error & $\mathrm{n}-(\mathrm{p}(1+\mathrm{r}))-1$ & $\sum_{i=1}^{n}\left(y_{i}-\hat{y}_{i}\right)^{2}$ & $\frac{\sum_{i=1}^{n}\left(y_{i}-\bar{y}_{i}\right)^{2}}{n-(p(1+r))-1}$ & \\
Total & $\mathrm{n}-1$ & $\sum_{i=1}^{n}\left(y_{i}-\bar{y}_{i}\right)^{2}$ & \\
\hline \hline
\end{tabular}

Dapat diambil keputusan daerah penolakan $H_{0}$ apabila nilai $F_{\text {hitung }}>F_{\alpha(p+p r ; n-(p+p r)-1)}$, yang berarti minimal terdapat satu parameter pada model regresi spline yang signifikan, atau minimal terdapat satu variabel prediktor yang berpengaruh terhadap respon.

2. Uji Parsial

Hipotesis dari pengujian parsial sebagai berikut.

$H_{0}: \beta_{j l}=0$

$H_{1}: \beta_{j l} \neq 0, j=1,2, \ldots, p ; l=1,2, . ., 1+r$

Statistik uji : $\quad t_{\text {hitumg }}=\frac{\hat{\beta}_{j l}}{\operatorname{se}\left(\hat{\beta}_{j l}\right)}$

$\operatorname{se}\left(\hat{\beta}_{j l}\right)$ adalah standart eror dari $\hat{\beta}_{j l}$ dimana $\operatorname{se}\left(\hat{\beta}_{j,(1+k)}\right)=\sqrt{\operatorname{var}\left(\hat{\beta}_{j,(1+k)}\right)}$, dengan $\operatorname{var}\left(\hat{\beta}_{j l}\right)$ merupakan elemen diagonal ke-jl dari matriks $\operatorname{var}(\hat{\beta})$. Daerah penolakan $\mathrm{H}_{0}$ adalah $\left|t_{\text {hitung }}\right|>t_{(\alpha / 2, n-(p(q+r))-1)}$.

Suatu model dikatakan baik ketika jika nilai $R^{2}$ yang diperoleh cukup tinggi. Nilai $R^{2}$ dapat dihitung dengan rumus pada persamaan berikut.

$$
R^{2}=\frac{S S R}{S S T}=\frac{\sum_{i=1}^{n}\left(\hat{y}_{i}-\bar{y}\right)^{2}}{\sum_{i=1}^{n}\left(y_{i}-\bar{y}\right)^{2}}
$$

\section{F. Pengujian Asumsi Residual IIDN}

Asumsi residual yang harus dipenuhi adalah identik, independen dan berdistribusi normal.

1. Uji Asumsi Identik

Asumsi identik terpenuhi adalah ketika varians residual bersifat homoskedastisitas [13]. Pendeteksian heteroskedastisitas residual dapat secara visual yaitu membuat plot antara residual dan estimasi respon serta dengan uji parsial yang dilakukan dengan cara melakukan regresi antara absolut residual model dengan variabel predictor [14].

2. Uji Asumsi Independen

Untuk melihat asumsi residual independen terpenuhi atau tidak maka dapat menggunakan plot ACF (Autocorrelation Function) dari residual [15]. Uji independen atau uji autokorelasi residual untuk mengetahui apakah ada korelasi antar residual, dapat juga dilakukan melalui uji DurbinWatson [16].

3. Uji Asumsi Distribusi Normal

Untuk melihat asumsi residual berdistribusi normal terpenuhi maka dapat dilihat ketika plot residual cenderung mengikuti garis normal dan pada histogram menunjukkan bentuk yang menyerupai kurva normal (lonceng). Pengujian dapat dilakukan dengan uji Kolmogorov Smirnov [17].

\section{H.Konsep Berpikir dan Kerangka Konsep}

Menurut BKKBN, yang menggambarkan perilaku seseorang atau masyarakat yang berkaitan dengan kesehatan mereka ditentukan oleh tiga faktor yaitu yang pertama faktor predisposisi terdiri dari pengetahuan, pendidikan, sikap, umur, budaya, dan ekonomi. Kedua yaitu faktor pemungkin yang terdiri dari sarana dan prasarana dan informasi kesehatan serta yang terakhir yaitu faktor pendorong yang terdiri dari sikap petugas kesehatan, perilaku tokoh masyarakat dan komitmen daerah.

Berdasarkan konsep tersebut menimbulkan faktor-faktor yang akan mempengaruhi unmet need di Kabupaten Gresik. Faktor tersebut adalah pengetahuan yang dapat dilihat pada pentingnya $\mathrm{KB}$ yang disampaikan melalui bantuan $\mathrm{PKB} / \mathrm{PLKB}$, pengetahuan keluaraga mengenai KB cukup penting untuk menurunkan anak tidak dikehendaki dalam keluarga yang tidak menggunakan KB, Sarana dan prasarana seperti tempat pelayanan $\mathrm{KB}$ merupakan tempat dimana layanan KB bagi masyarakat disuatu daerah dapat diakses dan dipenuhi, serta yang terakhir ekonomi dapat dilihat dari hasil pentahapan keluarga dimana keluarga dengan perekonomian rendah termasuk dalam kurang mengikuti program KB. Ketimpangan antar penduduk miskin terjadi pada penduduk berstrata ekonomi serta tingkat pendidikan yang rendah [18].

\section{Kebutuhan KB yang Belum Terpenuhi (Unmet Need)}

PUS yang ingin anak ditunda dan tidak ingin anak lagi, ingin ber-KB tetapi belum terlayani atau belum terpenuhi disebut unmet need [19].

$$
\% \text { unmet need }=\frac{\text { Jumlah PUS }(\text { tak KB })_{I A T+T I A L}}{\text { Jumlah PUS } S_{15-49}} \times 100 \%
$$

\section{J. Sumber Daya Pelayanan KB}

Unmet need digunakan untuk mengukur akses dan kualitas pelayanan KB yang tidak terpenuhi disuatu daerah, besar kemungkinan akan terjadi kehamilan yang tidak diinginkan. Kondisi ini dipengaruhi oleh komitmen daerah dalam pemenuhan akses informasi, jangkauan, dukungan dana, dan kualitas (tenaga, sarana dan prasarana) pelayanan KB [11]. Namun pada penelitian ini menggunakan pemenuhan akses informasi yang diperhitungkan dari cakupan layanan PKB/PLKB serta sarana dan prasarana yang dilihat dari cakupan tempat layanan $\mathrm{KB}$.

\section{K. Kriteria Pengukuran Kemiskinan}

Sebuah keluarga dikategorikan sebagai Pra-KS bila belum memenuhi kebutuhan dasarnya (basic needs) secara minimal atau belum bisa memnuhi indikator 1 hingga $5, \mathrm{KS} 1$ bila memnuhi indikator 1 sampai $5, \mathrm{KS} 2$ bila memenuhi indikator 1 hingga $14, \mathrm{KS} 3$ bila memenuhi indikator 1 hingga 21, dan dikategorikan KS3 plus bila memenuhi seluruh indikator 1 hingga 23 [20].

\section{Pendidikan}

Pembagian pendidikan menurut Depdiknas yaitu pendidikan dasar (SD, SMP), pendidikan menengah (SMA, MA, MAK), dan pendidikan tinggi (Akademi, PT). Tingkat pendidikan turut pula menentukan mudah tidaknya seseorang menyerap dan memahami pengetahuan yang mereka peroleh, pada umumnya semakin tinggi pendidikan seseorang makin baik pula pengetahuannya [21]. Pendidikan memberikan pemahaman yang lebih baik secara psikologis dan fisiologis dalam menggunakan alat atau cara KB tertentu dan akan mengurangi kemungkinan terjadinya unmet need [22]. 


\section{METODOLOGI PENELITIAN}

\section{A. Sumber Data}

Data yang digunakan dalam penelitian merupakan data sekunder pada Buku Program KBPP\&PA Kabupaten Gresik dalam Angka tahun 2017 yang didapatkan dari Badan Keluarga Berencana dan Pemberdayaan Perempuan Kabupaten Gresik.

\section{B. Variabel Penelitian}

Variabel respon (y) yang digunakan pada penelitian ini yaitu persentase unmet di Kabupaten Gresik pada tahun 2017 dengan variabel prediktor dan sumber dari penelitian sebelumnya sebagai berikut.

Tabel 2.

Variabel Penelitian

\begin{tabular}{clc}
\hline \hline Indikator & \multicolumn{1}{c}{ Variabel } & \multicolumn{1}{c}{ Sumber } \\
\hline$X_{1}$ & Cakupan PKB/PLKB & KBPP \& PA, 2017 \\
$X_{2}$ & Cakupan Tempat Pelayanan & KBPP \& PA, 2017 \\
$X_{3}$ & KB & KBPP \& PA, 2017 \\
& Persentase Keluarga Miskin & \\
& Persentase Pendidikan & KBPP \& PA, 2017 \\
$X_{4}$ & $\begin{array}{l}\text { Terakhir Lebih dari SMA } \\
\text { yang di Tamatkan Kepala } \\
\end{array}$ & \\
\hline \hline
\end{tabular}

\section{Struktur Data}

Struktur data yang digunakan pada penelitian ini menggunakan unit observasi yaitu 18 kecamatan di Kabupaten Gresik sebagai berikut.

Tabel 3.

Struktur Data

\begin{tabular}{cccccc}
\hline \hline Kecamatan & $\mathrm{Y}$ & $\mathrm{X}_{1}$ & $\mathrm{X}_{2}$ & $\mathrm{X}_{3}$ & $\mathrm{X}_{4}$ \\
\hline 1 & $\mathrm{Y}_{1}$ & $\mathrm{X}_{1,1}$ & $\mathrm{X}_{2,1}$ & $\mathrm{X}_{3,1}$ & $\mathrm{X}_{4,1}$ \\
$\vdots$ & $\vdots$ & $\vdots$ & $\vdots$ & $\vdots$ & $\vdots$ \\
$\vdots$ & $\vdots$ & $\vdots$ & $\vdots$ & $\vdots$ & $\vdots$ \\
18 & $\mathrm{Y}_{18}$ & $\mathrm{X}_{1,18}$ & $\mathrm{X}_{2,18}$ & $\mathrm{X}_{3,18}$ & $\mathrm{X}_{4,18}$ \\
\hline \hline
\end{tabular}

D.Langkah Analisis

Berikut ini merupakan langkah analisis yang digunakan dalam melakukan penelitian sebagai berikut.

1. Menginput data faktor yang mempengaruhi terhadap persentase unmet need tiap wilayah kecamatan di Kabupaten Gresik.

2. Mendeskripsikan karakteristik faktor yang mempengaruhi terhadap persentase unmet need tiap wilayah kecamatan di Kabupaten Gresik dengan menggunakan statistika deskriptif.

3. Membuat scatterplot antara variabel respon dengan masing-masing variabel prediktor.

4. Memodelkan data menggunakan regresi nonparametrik spline dengan satu knot, dua knot dan kombinasi knot agar hasil pemodelan tidak rumit

5. Menentukan titik knot optimal pada satu knot, dua knot dan kombinasi knot berdasarkan nilai GCV minimum.

6. Menetapkan model terbaik regresi nonparametrik spline dari nilai GCV minimum satu knot, dua knot dan kombinasi knot.

7. Menguji signifikansi parameter regresi spline secara serentak dan parsial.

8. Menghitung nilai koefisien determinasi $\left(\mathrm{R}^{2}\right)$.

9. Menguji Asumsi Residual Identik, Independen, Distribusi Normal.

10. Melakukan interpretasi tiap faktor dari model yang sudah didapatkan dan menarik kesimpulan.

\section{ANALISIS DAN PEMBAHASAN}

\section{A. Karakteristik Unmet Need}

Unmet need merupakan salah satu sasaran yang dirujuk oleh BKKBN dalam mengatasi masalah kependudukan khususnya dalam bidang Keluarga Berencana (KB).

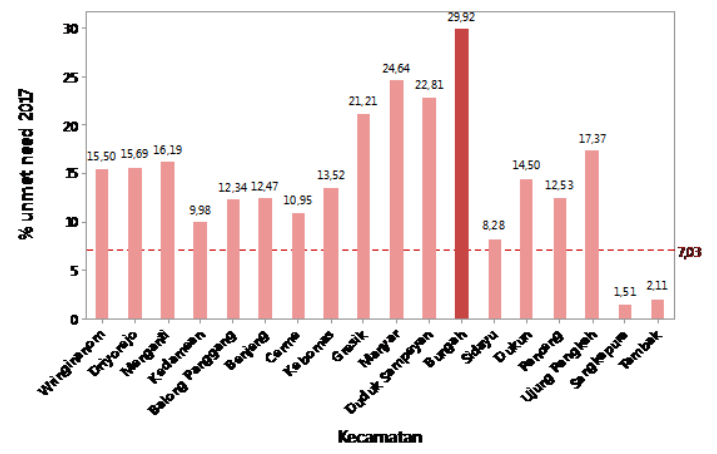

Gambar 1. Diagram Batang Persentase Unmet Need di Kabupaten Gresik.

Diagram batang diatas menunjukkan bahwa persentase unmet need tertinggi berada di Kecamatan Bungah yang mencapai 29,92 persen, hal tersebut dapat mengakibatkan kehamilan yang tidak diinginkan serta anak yang tumbuh kurang dari kasih sayang orang tua meningkat di wilayah tersebut. Sedangkan Kecamatan Sangkapura memiliki unmet need terendah di Kabupaten Gresik sebesar 1,51 persen, hal tersebut juga menandakan bahwa kepala keluarga didaerah tersebut banyak yang merantau ke Pulau Jawa maupun ke luar negeri sehingga seorang istri memilih untuk menjarangkan kehamilannya. Dari 18 kecamatan yang ada di Kabupaten Gresik terdapat 16 kecamatan yang memiliki nilai unmet need lebih besar dari target yang dicanangkan BKKBN Jawa Timur yaitu sebesar 7,03 persen. Berikut ini adalah karakteristik dari keempat variabel yang diduga memengaruhi unmet need di Kabupaten Gresik.

Tabel 4.

Unmet Need Tiap Kecamatan di Kabupaten Gresik

\begin{tabular}{ccccc}
\hline \hline Variabel & Rata-rata & Varians & Minimum & Maksimum \\
\hline$x_{1}$ & 7,117 & 3,885 & 3,200 & 17,000 \\
$x_{2}$ & 3,962 & 3,424 & 1,042 & 15,345 \\
$x_{3}$ & 28,66 & 7,918 & 15,61 & 40,61 \\
$x_{4}$ & 38,13 & 16,003 & 19,98 & 72,58 \\
\hline \hline
\end{tabular}

Rata-rata PKB dan PKB $\left(x_{l}\right)$ dalam menangani dan menjalankan tugasnya yaitu sebesar 7,117 yang berarti 1 orang PKB/PLKB di Kabupaten Gresik rata-rata menangani 7-8 desa dengan standar deviasi sebesar 3,885. Cakupan PKB/PLKB tertinggi pada Kecamatan Sangkapura, dimana 1 orang PKB/PLKB di kecamatan tersebut harus menangani 17 desa.

Rata-rata tempat layanan KB $\left(x_{2}\right)$ di Kabupaten Gresik yaitu sekitar 3-4 tempat pelayanan dengan keragaman tempat pelayanan KB diseluruh kecamatan di Kabupaten Gresik mencapai 3,424. Untuk kecamatan dengan cakupan tempat pelayanan KB tertinggi berada pada Kecamatan Gresik sebesar 15,345 yang berarti bahwa PUS di Kecamatan Gresik memiliki kesempatan untuk mendapatkan pelayanan KB di tempat tinggalnya cukup tinggi.

Rata-rata persentase keluarga miskin $\left(x_{3}\right)$ di Kabupaten Gresik mencapai 28,66 persen dengan keragaman persentase keluarga miskin di Kabupaten Gresik cukup tinggi yaitu 7,918. Persentase keluarga miskin terendah di Kabupaten Gresik berada di Kecamatan Driyorejo. 
Rata-rata persentase pendidikan lebih dari SMA yang ditamatkan KK $\left(x_{4}\right)$ di Kabupaten Gresik sebesar 38,13 persen dengan keragaman data yang sangat tinggi antar kecamatan di Kabupaten Gresik sebesar 16,003. Persentase pendidikan terakhir lebih dari SMA yang ditamatkan oleh KK tertinggi berada di Kecamatan Manyar yaitu sebesar 72,58 persen.

\section{B. Pemodelan Persentase Unmet Need di Kabupaten Gresik} Menggunakan Pendekatan Regresi Nonparametrik Spline Truncated

Sebelumnya dilakukan analisis deskriptif dari variabelvariabel yang diduga berpengaruh Unmet Need di Kabupaten Gresik untuk memastikan bahwa komponen yang digunakan merupakan komponen nonparametrik.

i. Pola Hubungan Unmet Need di Kabupaten Gresik dengan Faktor-faktor yang Diduga Mempengaruhi

Salah satu analisis deskriptif dari variabel-variabel yang diduga berpengaruh terhadap unmet need di Kabupaten Gresik adalah membuat scatterplot

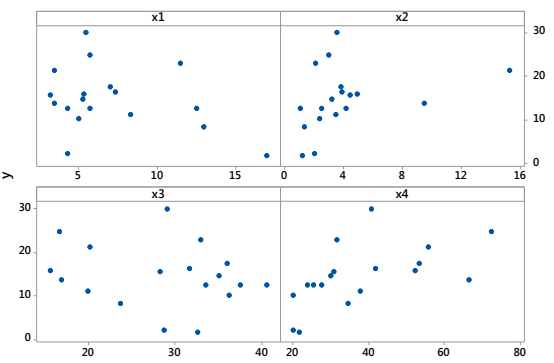

Gambar 2. Pola Hubungan Unmet Need dengan Variabel Prediktor.

Gambar 2 menunjukkan bahwa seluruh variabel prediktor dengan persentase unmet need di Kabupaten Gresik tidak membentuk suatu pola tertentu sehingga variabel-variabel tersebut termasuk dalam komponen nonparametrik. Selanjutnya akan dilakukan analisis menggunakan regresi nonparametrik spline truncated.

ii. Pemilihan Titik Knot Optimum

Pada penelitian ini, regesi nonparametrik spline truncated dengan derajat satu atau linier. Titik knot yang digunakan pada penelitian ini adalah satu knot, dua knot, dan kombinasi knot. Dari ketiga titik knot tersebut, untuk membentuk model digunakan titik knot optimum yang diperoleh dari nilai GCV yang minimum. Berikut hasil yang didapatkan.

1. Pemilihan Titik Knot dengan Satu Titik Knot

Estimasi model regresi nonparametrik spline truncated dengan satu titik knot pada unmet need di Kabupaten Gresik adalah sebagai berikut.

$$
\begin{gathered}
y_{i}=\beta_{0}+\beta_{11} x_{1 i}+\beta_{12}\left(x_{1 i}-K_{11}\right)_{+}+\beta_{21} x_{2 i}+\beta_{22}\left(x_{2 i}-K_{21}\right)_{+}+ \\
\beta_{31} x_{3 i}+\beta_{32}\left(x_{3 i}-K_{31}\right)_{+}+\beta_{41} x_{4 i}+\beta_{42}\left(x_{4 i}-K_{41}\right)_{+}+\varepsilon_{i}
\end{gathered}
$$

Nilai GCV pada satu titik knot dengan empat komponen nonparametrik yang paling minimum adalah 69,501 dengan titik knot optimum yaitu variabel cakupan PKB/PLKB $\left(x_{1}\right)$ pada titik 11,367; variabel cakupan tempat pelayanan $\mathrm{KB}$ $\left(x_{2}\right)$ pada titik 9,503; variabel persentase keluarga miskin $\left(x_{3}\right)$ pada titik 30,406; serta variabel pendidikan terakhir lebih dari SMA yang ditamatkan $\mathrm{KK}\left(x_{4}\right)$ pada titik 51,11.

2. Pemilihan Titik Knot dengan Dua Titik Knot

Estimasi model regresi nonparametrik spline truncated dengan dua titik knot pada unmet need di Kabupaten Gresik adalah sebagai berikut.

$$
\begin{aligned}
y_{i}= & \beta_{0}+\beta_{11} x_{1 i}+\beta_{12}\left(x_{1 i}-K_{11}\right)_{+}+\beta_{13}\left(x_{1 i}-K_{12}\right)_{+}+\beta_{21} x_{2 i}+ \\
& \beta_{22}\left(x_{2 i}-K_{21}\right)_{+}+\beta_{23}\left(x_{2 i}-K_{22}\right)_{+}+\beta_{31} x_{3 i}+\beta_{32}\left(x_{3 i}-K_{31}\right)_{+} \\
& +\beta_{33}\left(x_{3 i}-K_{32}\right)_{+}+\beta_{41} x_{4 i}+\beta_{42}\left(x_{4 i}-K_{41}\right)_{+}+\beta_{43}\left(x_{4 i}-K_{42}\right)_{+} \\
& +\varepsilon_{i}
\end{aligned}
$$

Nilai GCV pada dua titik knot dengan empat komponen nonparametrik yang paling minimum adalah 53,12 dengan titik knot optimum yaitu variabel cakupan PKB/PLKB $\left(x_{1}\right)$ pada titik 8,551 dan 9,114; variabel cakupan tempat pelayanan $\mathrm{KB}\left(x_{2}\right)$ pada titik 6,585 dan 7.169; variabel persentase keluarga miskin $\left(x_{3}\right)$ pada titik 25,304 dan 26,324; serta variabel pendidikan terakhir lebih dari SMA yang ditamatkan KK $\left(x_{4}\right)$ pada titik 40,376 dan 42,523.

3. Pemilihan Titik Knot dengan Kombinasi Titik Knot

Nilai GCV pada kombinasi titik knot dengan empat komponen nonparametrik yang paling minimum adalah 38,285 dengan titik knot optimum yaitu variabel cakupan PKB/PLKB $\left(x_{1}\right)$ pada titik 11,367; variabel cakupan tempat pelayanan KB $\left(x_{2}\right)$ pada titik 9,503 ; variabel persentase keluarga miskin $\left(x_{3}\right)$ pada titik 25,304, dan 26,324; serta variabel pendidikan terakhir lebih dari SMA yang ditamatkan KK $\left(x_{4}\right)$ pada titik 40,376 dan 42,523.

iii. Pemilihan Model Terbaik

Setelah mendapatkan nilai GCV minimum pada pemilihan titik knot optimum dengan satu titik knot, dua titik knot dan kombinasi knot, selanjutnya dilakukan pemilihan model terbaik dengan membandingkan nilai GCV.

Tabel 5.

Perbandingan Nilai GCV Minimum

\begin{tabular}{cc}
\hline \hline Jumlah Knot & GCV Minimum \\
\hline Satu Titik Knot & 69.50142 \\
Dua Titik Knot & 53.11973 \\
Kombinasi Titik Knot & 38.285 \\
\hline \hline
\end{tabular}

Berdasarkan Tabel 5 diketahui bahwa pemodelan yang menghasilkan nilai GCV terkecil adalah pemodelan regresi nonparametrik spline truncated dengan menggunakan kombinasi titik knot pada empat variabel prediktor yang seluruhnya termasuk komponen nonparametrik.

iv. Pemodelan Unmet Need di Kabupaten Gresik dengan Menggunakan Titik Knot Optimum

Estimasi model untuk regresi nonparametrik spline truncated linier dengan derajat satu dengan kombinasi titik knot dengan rincian satu titik knot variabel $x_{1}$, satu titik knot pada variabel $x_{2}$, dua titik knot pada variabel $x_{3}$, serta dua titik knot pada variabel $x_{4}$ adalah sebagai berikut.

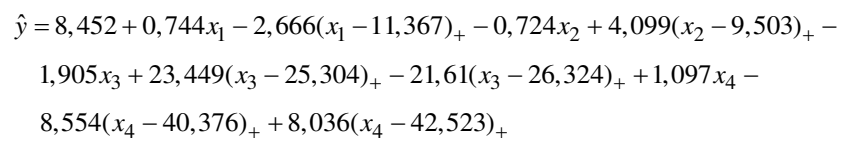

v. Pengujian Signifikansi Parameter Model Regresi Nonparametrik Spline Truncated

Pengujian dilakukan dengan dua tahap, yaitu pengujian parameter secara serentak dan individu.

1. Pengujian Serentak

Hipotesis yang digunakan untuk pengujian secara serentak adalah sebagai berikut.

$\mathrm{H}_{0}: \beta_{11}=\beta_{12}=\ldots=\beta_{43}=0$

$\mathrm{H}_{1}$ : minimal terdapat satu $\beta_{j l} \neq 0 ;$ dengan $j=1,2, \ldots, 10$;

$$
l=1,2, \ldots, 1+r
$$


Tabel 6.

Hasil Pengujian Serentak

\begin{tabular}{lrrrrr}
\hline \hline Sumber & \multicolumn{1}{c}{ df } & \multicolumn{1}{l}{ SS } & \multicolumn{1}{c}{ MS } & Fhit & P-Value \\
\hline Regresi & 10 & 771.551 & 77.155 & 5.182 & 0.0198 \\
Error & 7 & 104.22 & 14.889 & & \\
Total & 17 & 875.772 & & & \\
\hline \hline
\end{tabular}

F hitung yang didapatkan dari uji signifikansi parameter secara serentak pada pemodelan regresi nonparametrik spline truncated yaitu sebesar 5,18 dan pvalue sebesar 0,0198. Taraf signifikansi $(\alpha)$ yang digunakan sebesar 10\% maka didapatkan keputusan tolak $\mathrm{H}_{0}$ karena nilai $\mathrm{F}$ lebih besar dari $\mathrm{F}_{(0,1 ; 10,7)}$, yaitu 5,182 > 2,702 dan $P$-value $<\alpha$, sehingga dapat disimpulkan bahwa minimal terdapat satu parameter pada model yang signifikan.

Koefisien determinasi $\left(R^{2}\right)$ yang diperoleh adalah $88,09 \%$. Hal ini menunjukkan bahwa model mampu menjelaskan keragaman unmet need di Kabupaten Gresik sebesar 88,09\%, sedangkan sisanya dijelaskan oleh variabel lain yang tidak masuk dalam model.

2. Pengujian Individu

Berikut merupakan perumusan hipotesis yang digunakan.

$\mathrm{H}_{0}: \beta_{j l}=0$

$\mathrm{H}_{1}: \beta_{j l} \neq 0, \mathrm{j}=1,2,3,4 ; l=1,2, \ldots, 1+r$

Tabel 7.

Hasil Pengujian Individu

\begin{tabular}{cccccc}
\hline \hline Variabel & Parameter & Estimasi & $\mathrm{t}$ & Keputusan & Kesimpulan \\
\hline \multirow{2}{*}{$x_{1}$} & $\beta_{11}$ & 0,744 & 1,520 & Gagal tolak & \\
& $\beta_{12}$ & $-2,666$ & $-2,004$ & Tolak & \\
\hline \multirow{3}{*}{$x_{2}$} & $\beta_{21}$ & $-0,724$ & $-1,038$ & Gagal tolak & \\
& $\beta_{22}$ & 4,099 & 2,594 & Tolak & Berpengaruh \\
& $\beta_{31}$ & $-1,905$ & $-2,058$ & Tolak & \\
\multirow{3}{*}{$x_{3}$} & $\beta_{32}$ & 23,449 & 3,357 & Tolak & Berpengaruh \\
& $\beta_{33}$ & $-21,610$ & $-3,419$ & Tolak & \\
\hline \multirow{4}{*}{$x_{4}$} & $\beta_{41}$ & 1,097 & 4,578 & Tolak & \\
& $\beta_{42}$ & $-8,554$ & $-3,015$ & Tolak & Berpengaruh \\
& $\beta_{43}$ & 8,036 & 2,856 & Tolak & \\
\hline \hline
\end{tabular}

Hasil dari pengujian individu dengan taraf signifikan ( $\alpha$ ) sebesar $10 \%$, seluruh variabel berpengaruh signifikan. Dari 10 parameter pada model regresi nonparametrik spline truncated, terdapat 8 parameter yang signifikan dan 2 parameter yang tidak signifikan.

vi. Pengujian Asumsi Residual

1. Pengujian Asumsi Identik

Hasil uji Glejser akan ditampilkan pada Tabel berikut.

Tabel 8.

ANOVA Uji Glejser

\begin{tabular}{cccccc}
\hline \hline Sumber & DF & SS & MS & F-Hitung & P-Value \\
\hline Regresi & 4 & 14,208 & 3,552 & 1,71 & 0,208 \\
Error & 13 & 27,012 & 2,078 & & \\
Total & 17 & 41,219 & & & \\
\hline \hline
\end{tabular}

Berdasarkan Tabel 4.8 diketahui bahwa nilai $\mathrm{F}$ yang dihasilkan adalah 1,71 dan P-value sebesar 0,208. Dengan taraf signifikansi $(\alpha)$ sebesar $10 \%$ maka didapatkan keputusan gagal tolak $\mathrm{H}_{0}$ karena nilai $\mathrm{F}<\mathrm{F}_{(0,1 ; 4,13)}$, yaitu 1,71 $<2,434$ dan $P$-value $>\alpha$, sehingga dapat disimpulkan bahwa tidak terjadi heteroskedastisitas atau variansi antar residual sama. Hal ini berarti bahwa asumsi residual identik telah terpenuhi.
2. Pengujian Asumsi Independen

Cara untuk mengetahui ada atau tidaknya autokorelasi antar residual adalah dengan menggunakan Plot Autocorrelation Function (ACF).

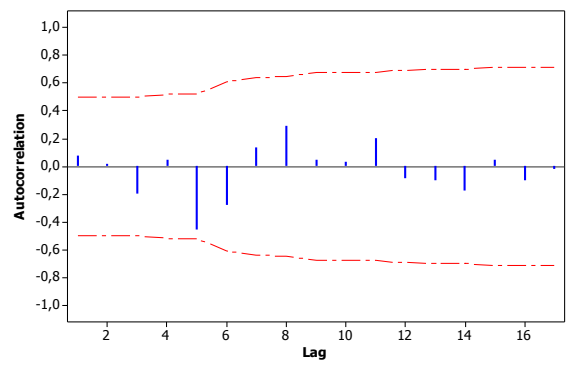

Gambar 3. Plot ACF Residual.

Tidak ada nilai autokeralasi pada lag berapapun yang keluar dari batas atas maupun batas bawah (batas interval konfidensi), sehingga tidak terdapat autokorelasi antar residual. Untuk memperkuat hasil dilakukan pengujian durbin watson dan hasil yang didapatkan yaitu sebesar 2,184 dengan $\mathrm{d}_{\mathrm{u}}$ 1,6 maka gagal tolak $\mathrm{H}_{0}$ atau tidak terjadi kasus autokorelasi. Hal ini mengindikasikan bahwa asumsi independen pada residual model telah terpenuhi.

3. Pengujian Asumsi Distribusi Normal

Pengujian ini dilakukan dengan uji KolmogorovSmirnov. Hasil uji Kolmogorov-Smirnov ditampilkan pada gambar berikut.

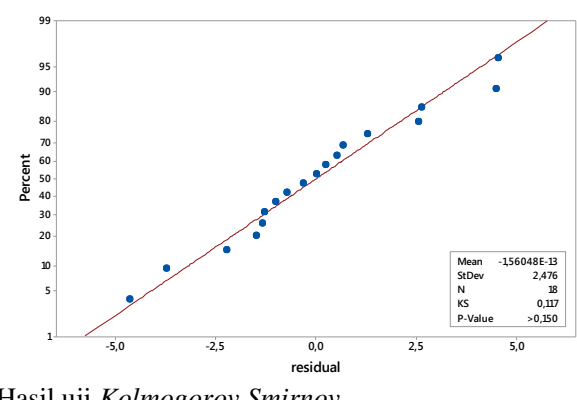

Gambar 4. Hasil uji Kolmogorov Smirnov.

Plot residual model yang telah mendekati garis linier, selain itu juga diketahui nilai Kolmogorov Smirnov 0,117. Nilai tersebut lebih kecil dari $\mathrm{q}_{(1-\alpha)}$ pada taraf signifikansi $(\alpha)$ sebesar $10 \%$ yaitu dan p-value yang dihasilkan lebih besar dari 0,15 sehingga gagal tolak $\mathrm{H}_{0}$. Hal ini menunjukkan bahwa residual model regresi nonparametrik spline truncated telah memnuhi asumsi distribusi normal.

vii. Interpretasi Model Regresi Nonparametrik Spline Truncated

Model regesi yang terbentuk menggunakan titik knot optimum, yaitu kombinasi titik knot yang ditunjukkan pada persamaan sebagai berikut.

1. Pengaruh variabel cakupan PKB/PLKB $\left(x_{l}\right)$ terhadap unmet need tiap kecamatan di Kabupaten Gresik dengan mengasum-sikan variabel lainnya konstan dapat ditulis sebagai berikut.

$$
\begin{aligned}
\hat{y} & =0,744 x_{1}-2,666\left(x_{1}-11,367\right)_{+}+c \\
& =\left\{\begin{array}{lr}
0,744 x_{1}+c & ; x_{1}<11,367 \\
30,304-1,922 x_{1}+c & ; x_{1} \geq 11,367
\end{array}\right.
\end{aligned}
$$

Berdasarkan model diatas, dapat diketahui bahwa pada interval pertama yaitu untuk cakupan PKB/PLKB $\left(x_{1}\right)$ yang kurang dari 11.367 yang berarti apabila cakupan PKB/PLKB bertambah satu satuan maka unmet need di Kabupaten 
Gresik akan meningkat sebesar 0.744. Sedangkan untuk interval kedua yaitu cakupan PKB/PLKB $\left(x_{1}\right)$ yang lebih dari sama dengan 11.367 yang berarti apabila cakupan PKB/PLKB bertambah satu satuan maka unmet need di Kabupaten Gresik akan menurun sebesar 1.922 . Interval pertama terdiri dari 14 kecamatan yang ada di Kabupaten Gresik yaitu Kecamatan Tambak, Panceng, Ujungpangkah, Dukun, Bungah, Manyar, Gresik, Kebomas, Cerme, Benjeng, Menganti, Kedamean, Driyorejo dan Wringinanom. Sedangkan untuk interval kedua terdiri dari 4 kecamatan yaitu Kecamatan Sangkapura, Sidayu, Duduksampeyan dan Balongpanggang.

2. Pengaruh variabel cakupan tempat pelayanan KB $\left(x_{2}\right)$ terhadap unmet need tiap kecamatan di Kabupaten Gresik dengan mengasumsikan variabel lainnya konstan dapat ditulis sebagai berikut.

$$
\begin{aligned}
\hat{y} & =-0,724 x_{2}+4,099\left(x_{2}-9.503\right)_{+}+c \\
& = \begin{cases}-0,724 x_{2}+c & ; x_{2}<9,503 \\
3,357 x_{2}-38,953+c & ; x_{1} \geq 9,503\end{cases}
\end{aligned}
$$

Berdasarkan model diatas, dapat diketahui bahwa interval pertama yaitu untuk cakupan tempat pelayanan $\mathrm{KB}$ $\left(x_{2}\right)$ yang kurang dari 9.503 yang berarti apabila cakupan tempat pelayanan $\mathrm{KB}$ bertambah satu satuan maka persentase unmet need akan menurun sebesar 0.742 di wilayah tersebut. Untuk interval kedua yaitu cakupan tempat pelayanan KB yang lebih dari sama dengan 9.503 dimana apabila variabel tersebut bertambah satu satuan maka persentase unmet need akan bertambah sebesar 3.357 di wilayah yang terkait interval tersebut. Kecamatan yang masuk dalam interval pertama hampir seluruh kecamatan yang ada di Kabupaten Gresik kecuali Kecamatan Gresik merupakan satu-satunya kecamatan yang masuk dalam interval kedua.

3. Dengan mengasumsikan variabel prediktor selain persentase keluarga miskin $\left(x_{3}\right)$ konstan, maka pengaruh variabel persentase keluarga miskin terhadap unmet need di Kabupaten Gresik dapat ditulis sebagai berikut.

$$
\begin{aligned}
\hat{y} & =1,905 x_{3}+23,449\left(x_{3}-25,304\right)_{+}-21,61\left(x_{3}-26,324\right)_{+}+c \\
& = \begin{cases}1,905 x_{3}+c \quad ; x_{3}<25,304 \\
25,354 x_{3}-593,353+c & ; 25,304 \leq x_{3}<26,324 \\
3,744 x_{3}-24,491+c & ; x_{3} \geq 26,324\end{cases}
\end{aligned}
$$

Berdasarkan model diatas didapatkan tiga interval yang memperlihatkan perubahan pola data pada persentase keluarga miskin di Kabupaten Gresik. Interval pertama merupakan persentase keluarga miskin yang kurang dari 25.304 persen, yang berarti bahwa apabila persentase keluarga miskin meningkat satu persen maka persentase unmet need di kecamatan tersebut akan meningkat pula sebesar 1.905 persen. Sedangkan untuk interval kedua merupakan persentase keluarga miskin yang lebih dari sama dengan 25.354 persen hingga kurang dari 26.324 persen, yang dapat dikatakan bahwa jika persentase keluarga miskin naik satu persen pada kecamatan yang tergolong dalam interval kedua maka persentase unmet need di kecamatan terkait akan meningkat pula sebesar 25.354 persen. Interval ketiga merupakan interval untuk kelompok kecamatan yang tergolong dalam persentase keluarga miskin lebih dari sama dengan 26.324 persen. Hal tersebut mengartikan bahwa tiap pertambahan satu persen keluarga miskin pada kecamatan yang termasuk dalam interval ketiga maka persentase unmet need di kecamatan tersebut akan meningkat sebesar 3.744 persen. Persentase keluarga miskin interval pertama yaitu Kecamatan Sidayu, Manyar, Gresik, Kebomas, Cerme dan Driyorejo. Sedangkan kecamatan yang tergolong dalam interval ketiga mencakup hampir seluruh kecamatan yang ada di Kabupaten Gresik yaitu Kecamatan Tambak, Sangkapura, Ujungpangkah, Panceng, Dukun, Bungah, Duduksampeyan, Benjeng, Balongpanggang, Menganti, Kedamean dan Wringinanom. Untuk interval kedua tidak terdapat kecamatan yang tergolong dalam persentase keluarga miskin dalam rentang tersebut.

4. Dengan mengasumsikan variabel prediktor selain persentase pendidikan terakhir lebih dari SMA yang ditamatkan $\mathrm{KK}\left(x_{4}\right)$ konstan, maka pengaruh variabel persentase pendidikan terakhir lebih dari SMA yang ditamatkan KK terhadap unmet need di Kabupaten Gresik dapat ditulis sebagai berikut

$$
\begin{aligned}
\hat{y} & =1,097 x_{4}-8,554\left(x_{4}-40,376\right)_{+}+8,036\left(x_{4}-42,523\right)_{+}+c \\
& = \begin{cases}1,097 x_{4}+c & ; x_{4}<40,376 \\
345,376-7.45 x_{4}+c & ; 40,376 \leq x_{3}<42,523 \\
0,579 x_{4}-3,661+c & ; x_{3} \geq 42,523\end{cases}
\end{aligned}
$$

Berdasarkan model diatas dapat dilihat bahwa variabel persentase pendidikan terakhir lebih dari SMA yang ditamatkan $\mathrm{KK}\left(x_{4}\right)$ terbagi menjadi tiga interval dengan tiap intervalnya memiliki kecamatan yang masuk dalam kategori interval tersebut. Interval pertama merupakan persentase pendidikan terakhir lebih dari SMA yang ditamatkan KK kurang dari 40.376 , yang berarti bahwa jika persentase pendidikan terakhir lebih dari SMA yang ditamatkan KK bertambah satu persen maka persentase unmet need di kecamatan tersebut akan meningkat sebesar 1.097persen. Untuk interval kedua merupakan persentase pendidikan terakhir lebih dari SMA yang ditamatkan KK lebih dari sama dengan 40.376 sampai kurang dari 42.523, yang berarti apabila persentase pendidikan terakhir lebih dari SMA yang ditamatkan KK meningkat sebesar satu persen maka persentase unmet need akan menurun sebesar 7.45 persen. Yang terakhir untuk interval ketiga dimana persentase pendidikan terakhir lebih dari SMA yang ditamatkan KK lebih dari sama dengan 42.523, yang dapat diartikan bahwa apabila variabel tersebut naik sebesar satu satuan maka persentase unmet need akan meningkat sebesar 0.579 persen. Kecamatan yang termasuk dalam interval pertama yaitu sebanyak 11 kecamatan yang terdiri dari Kecamatan Tambak, Sangkapura, Panceng, Dukun, Sidayu, Duduksampeyan, Cerme, Benjeng, Balongpanggang, Kedamean dan Wringinanom. Sedangkan kecamatan yang masuk dalam interval kedua adalah Kecamatan Bungah dan Menganti, sedangkan wilayah yang masuk interval ketiga yaitu terdiri dari Kecamatan Ujungpangkah, Manyar, Gresik, Kebomas dan Driyorejo.

Setelah dilakukan interpretasi mengenai model unmet need di Kabupaten Gresik tahun 2017 berdasarkan faktorfaktor yang mempengaruhi tersebut, maka dapat dibandingkan hasil antara persentase unmet need aktual $(y)$ dengan persentase unmet need taksiran ( $\hat{y}$ ) sebagai berikut. 


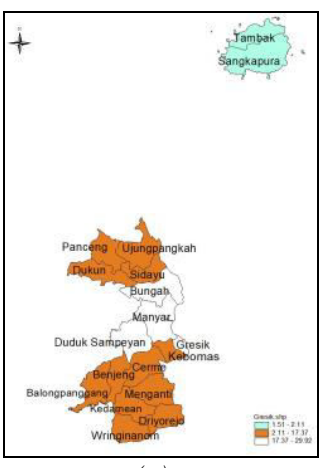

(a)

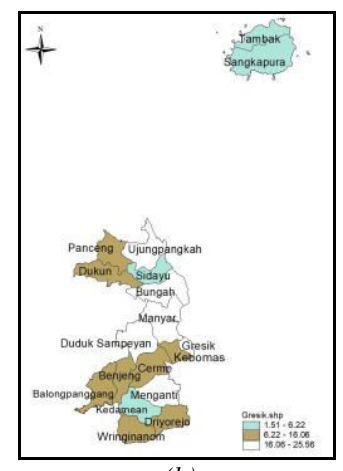

(b)

Gambar 4. Peta Persentase Unmet Need tiap kecamatan di Kabupaten Gresik.

Gambar 4 (a) merupakan peta persentase unmet need aktual ( $y$ ) sedangkan Gambar 4 (b) merupakan persentase unmet need taksiran $(\hat{y})$. Dapat dilihat bahwa pada peta persentase unmet need aktual $(y)$ yang tergolong dalam wilayah dengan persentase unmet need tinggi adalah Kecamatan Bungah, Manyar, Duduk Sampeyan dan Gresik sedangkan wilayah yang tergolong persentase unmet need rendah adalah Kecamatan Tambak dan Kecamatan Sangkapura yang berada di Pulau Bawean. Hal tersebut menjadi berbeda pada peta persentase unmet need taksiran $(\hat{y})$ yang didapatkan berdasarkan model dengan faktor-faktor yang mempengaruhi. Dapat dilihat bahwa terdapat bebrapa wilayah yang berubah kategori baik semakin meningkat ataupun menurun, seperti pada Kecamatan Ujungpangkah yang semula tergolong dalam persentase unmet need sedang menjadi persentase unmet need tinggi setelah mempertimbangkan faktor-faktor yang mempengaruhi serta begitu pula pada Kecamatan Menganti. Terdapat dua kecamatan yang semula tergolong dalam persentase unmet need sedang menjadi persentase unmet need rendah, yaitu Kecamatan Kedamean dan Sidayu. Sedangkan wilayah lainnya masih tergolong pada persentase unmet need yang sama. Berdasarkan hasil tersebut seharusnya pemerintah lebih sesuai dalam memberikan pelayanan yang secara optimal baik dari segi masyarakatnya sendiri ataupun dari segi pendukungnya.

\section{viii. KESIMPULAN DAN SARAN}

\section{A. Kesimpulan}

Persentase unmet need di Kabupaten Gresik tahun 2017 menempati urutan kedua terendah di Provinsi Jawa Timur,hal ini ditunjukkan dengan adanya 16 kecamatan dari 18 kecamatan yang memiliki persentase jauh diatas target pemerintah. Model regresi nonparametrik spline truncated terbaik dalam pemodelan persentase unmet need di Kabupaten Gresik adalah menggunakan kombinasi titik knot, Seluruh variabel prediktor berpengaruh signifikan dengan model sebagai berikut.

$$
\begin{aligned}
\hat{y}= & 8.452+0.744 x_{1}-2.666\left(x_{1}-11.367\right)_{+}^{1}-0.724 x_{2}+4.099\left(x_{2}-9.503\right)_{+}^{1}- \\
& 1.905 x_{3}+23.449\left(x_{3}-25.304\right)_{+}^{1}-21.61\left(x_{3}-26.324\right)_{+}^{1}+1.097 x_{4}- \\
& 8.554\left(x_{4}-40.376\right)_{+}^{1}+8.036\left(x_{4}-42.523\right)_{+}^{1}
\end{aligned}
$$

Nilai koefisien determinasi yang dihasilkan oleh model tersebut sebesar $88.09 \%$.

\section{B. Saran}

Saran yang diberikan oleh penulis yaitu sebaiknya pemerintah lebih memperhatikan faktor-faktor apa saja yang

berpengaruh terhadap unmet need, serta memberikan perhatian lebih dari kondisi tiap wilayah yang ada. Selain itu juga pemerintah dapat membuat kebijakan terkait bidang kependudukan khusunya KB di Kabupaten Gresik.

\section{DAFTAR PUSTAKA}

[1] H. Purnomo, "Negara dengan penduduk terbanyak di dunia, RI masuk 4 besar," finance.detik.com, 2014. [Online]. Available: http://finance.detik.com/read/2014/03/06/134053/2517461/4/neg ara-dengan-penduduk-terbanyak-di-dunia-ri-masuk-4-besar.

[2] BKKBN, "Petunjuk Teknis Penggunaan Dana Alokasi Khusus Subbidang Keluarga Berencana Tahun 2014,” Jakarta, 2013.

W. R. E., Pengantar Statistika Edisi ke-3. Jakarta: Gramedia Pustaka Utama, 1995.

[4] I. Budiantara, "Estimator Spline Terbobot dalam Regresi Semiparametrik," Maj. Ilmu Pengetah. dan Teknol., vol. 10, pp. 103-109, 1999.

[5] R. L. Eubank, Nonparametric Regression and Spline Smoothing, Second Edition. New York: Taylor \& Francis, 1999.

[6] A. A. Fernandes, I. N. Budiantara, B. W. Otok, and Suhartono. "Reproducing Kernel Hilbert Space for Penalized Regression Multi Predictors: Case in Longitudinal Data," Int. J. Math. Anal., vol. 8, no. 40, pp. 1951-1961, 2014

[7] A. A. Fernandes, I. N. Budiantara, B. W. Otok, and Suhartono., "Spline Estimator for Bi-Response and Multi-Predictors Nonparametric Regression Model in Case of Longitudinal Data," J. Math. Stat., vol. 11, no. 2, pp. 61-69, 2015.

[8] Sugiantari, Ayuk Putri, Budiantara, I Nyoman, "Analisis FaktorFaktor yang Mempengaruhi Angka Harapan Hidup di Jawa Timur Menggunakan Regresi Semiparametrik Spline," J. Sains dan Deni Pomits, vol. 2, 2013.

[9] I. Budiantara, "Penelitian Bidang Regresi Spline Menuju Terwujudnya Penelitian Statistika yang Mandiri dan Berkarakter," in Makalah Pembicara Utama pada Seminar Nasional FMIPA, 2011.

[10] S. F. Nisa' and I. Budiantara, "Analisis Survival dengan Pendekatan Multivariate Adaptive Regression SPline pada Kasus Demam Berdarah Dengue (DBD)," J. Sains dan Seni ITS, pp. D318-D323, 2012.

[11] G. Wahba, Spline Models for Observation Data. Dalam CBMS NSF Regional Conference Series in Applied Mathematic. Philadelphia: SIAM, 1990.

[12] A. Tripena and I. Budiantara, "Fourier Estimator in Nonparametric Regression," in International Conference on Natural and Applied Natural Science, 2006, pp. 2-4.

[13] B. Lestari, I. N. Budiantara, S. Sunaryo, and M. Mashuri, "Spline Smoothing for Multiresponse Nonparametric Regresssion Model in Case of Heteroscedasiticity of Variace," J. Math. Stat., pp. 377-384, 2012.

[14] D. Montgomery, Desain and Analysis of Experiment, 5th ed. New York: John Wiley and Sons, Inc, 2001.

[15] W. W. S. Wei, Time Series Analysis Univariate and Multivariate Methods. Pearson Education, Inc, 2006.

[16] D. N. Gujarati, Basic Econometrics, 4th ed. New York: Mc Graw Hill, 2004.

[17] W. Daniel, Statistika Non Parametrik. Jakarta: Gramedia, 1989.

[18] I. Wulandari and I. N. Budiantara, "Analisis Faktor-faktor yang Mempengaruhi Persentase Penduduk Miskin dan Pengeluaran Perkapita Makanan di Jawa Timur Menggunakan Regresi Nonparametrik Birespon Spline," J. Sains dan Seni, pp. D30D35, 2014.

[19] KBPP Kabupaten Gresik, "Standar Pelayanan Minimal (SPM)," Gresik, 2015.

[20] A. Suryahadi, Akhmadi, and W. Isdijoso, "Penetapan Kriteria dan Variabel Pendataan Penduduk Miskin yang Komprehensif dalam Rangka Perlindungan Penduduk Miskin di Kabupaten/Kota,” Kertas Kerja SMERU, pp. 5-6, 2014.

[21] Hary, Pengetahuan Menurut Tingkat Pendidikan. Bandung: Pustaka Harapan, 2006.

[22] M. Isa, "Determinan Unmet Need Keluarga Berencana di Indonesia: Analisis Data Survei Demografi dan Kesehatan Indonesia 2007," Depok, 2009. 